\title{
Evaluation of Energy Conservation with Utilization of Marble Waste in Geotechnical Engineering
}

\section{Nazile Ural ${ }^{*}$}

Bilecik Seyh Edebali University, Department of Civil Eng., 11210, Bilecik, Turkey

\begin{abstract}
Nowadays one of the goals of all the countries has been to improve the international competitiveness and ensure a sustainable economy. This situation has become even more important with the increasing in population, consumption and rapid decreasing natural resources. Consumption of natural resources is created negative in terms of sustainable development with environmental problems. In addition, also, it is given the reason people's lives to reduce the energy needed to sustain a healthy and comfortable. Thus, recycling qualified wastes are a very substantial topic. In this study, the use of marble waste in geotechnical engineering, and the gains for energy to be obtained by recycling of its discussed.
\end{abstract}

\section{Keywords: Stabilization; Solid waste; Geotechnical}

\section{Introduction}

The industrial wastes can cause the environmental problem in the world. If we look at the issue in terms of sustainability, the reuse of these wastes is necessary. Especially, for many years large amounts of stone wastes are generated in the quarry processing plants. The environment, humans and economy are impacted significant because of these wastes. Especially, consumption increases with the increase of population in the world and with consumption our natural resources is rapidly declining. However, rapid economic growth, urbanization, rising population and increasing welfare leads to increasing amount of production waste. That large amounts of waste materials are required particularly in the construction industry, road construction, the construction of waste storage areas, and concrete manufacture makes recycling. Today, with the rapid growth of the industry is in excess of industrial wastes increased the performance of work on the evaluation of waste. Utilizing industrial waste provides both prevention of environmental pollution caused by waste and contribution to the national economy by using industrial waste in the construction industry.

Such industrial wastes as marble waste (pieces and dust), molding sand, fly ash, glass dust and sewage sludge are wastes that are environmentally harmful but contribute to national economy if they are recycled. Marble, mankind has lived in the area for centuries, it is particularly used because it is robust. Today, increasingly marble with the request of the construction sector development and better living people began to more consumption. The development of the marble industry and the rapid increase of the company has required an assessment of the marble waste.

There are many countries of the marble and stone quarries and marble the company in the world. Especially, Italy, Turkey, Spain, India and China are the top five dominant countries in terms of marble production [1]. A major part of production is consumed locally by producing countries, and only a small percentage of total production is exported. This fact indicates that local supply of marble remains less costly, while the transportation cost increases the price of exported marble products. Therefore, Afghan firms can win the domestic market with least effort. In addition to, Korai [2] was given world top ten marble exporters (China, Italy, Germany, Turkey, India, Japan, United States of America, Spain, Brazil and France) and importers (United States of America, China, Germany, Republic of Korea, Japan, Italy, France, United Kingdom, Netherlands and Belgium). However, Afghan and Pakistani are more the domestic market [1]. it is seems that in the marble quarries of marble company emerged stone (marble) wastes in many countries. Constitute a significant portion of exports marble sector is growing rapidly in these countries. Sector grows, increases, the rate of waste left behind. Especially, in case uncontrolled spillage of waste, some environmental problems occur. Figure 1a is given image noise created by the marble waste, and Figure $1 \mathrm{~b}$ is given waste from marble company, Bilecik, TURKEY. However, marble dust is left to nature in the form of aqueous sludge at the end of cutting process. Because of marble dust is uncontrollably left to nature, it damages to the environment that marble waste reduces water filtering capacity of the soil, prevents the development of vegetation, fills stream beds and contaminates water resources [3].

In bearing capacity weak soil, for the removal of existing soil, it is occured another area to transport, and instead of taking the high strength material handling, transportation, laying operations. The resulting new business processes, increase rental of construction equipment, fuel costs, labor costs, shipping charges, the unloading and storage costs. However, by adding additives to existing soil is provided the gain of said energy. By improving the application of lime, can provide up to $40 \%$ economy [4]. The contribution of the waste material, this will further increase the economic benefits. It is used marble dust and marble aggregate in geotechnical engineering. Marble dust is used very the department of building materials [5-10]. At the same time, department of transportation is used marble waste. Karaşahin and Terzi [11] investigated, the evaluation of waste marble dust covering layer. They said that local road in marble dust can be used as filler material in asphalt material. Seung and Fishman [12] studied a variety of aggregate wastes and fly ash were used in soil base. The experiments shown that waste aggregate and fly ash increased permeability and reduced plasticity was observed. Okagbue and Onyeobi [13] examined variation of geotechnical properties of three different red tropical soils by adding varying degrees of marble dust. Yhey were shown that

*Corresponding author: Nazile Ural, Bilecik Seyh Edebali University, Department of Civil Eng., 11210, Bilecik, Turkey, E-mail: nazile.ural@bilecik.edu.tr

Received March 12, 2015; Accepted December 11, 20155; Published December 18,2015

Citation: Ural N (2015) Evaluation of Energy Conservation with Utilization of Marble Waste in Geotechnical Engineering. Int J Waste Resour 5: 189. doi: 10.4172/2252-5211.1000189

Copyright: (c) 2015 Ural N, et al. This is an open-access article distributed under the terms of the Creative Commons Attribution License, which permits unrestricted use, distribution, and reproduction in any medium, provided the original author and source are credited. 


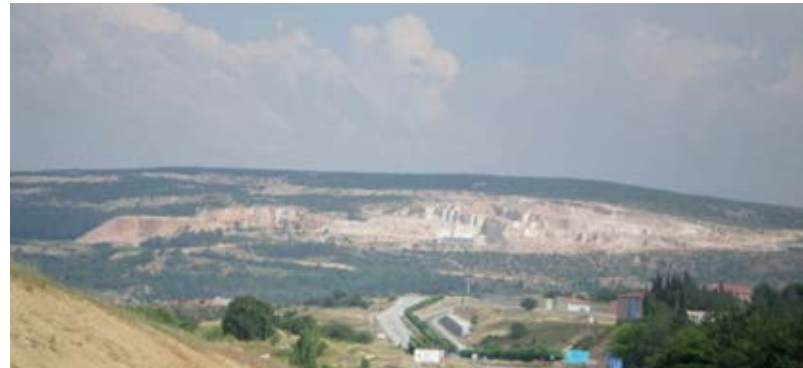

Figure 1: (a) Waste storage, Bilecik, Turkey.

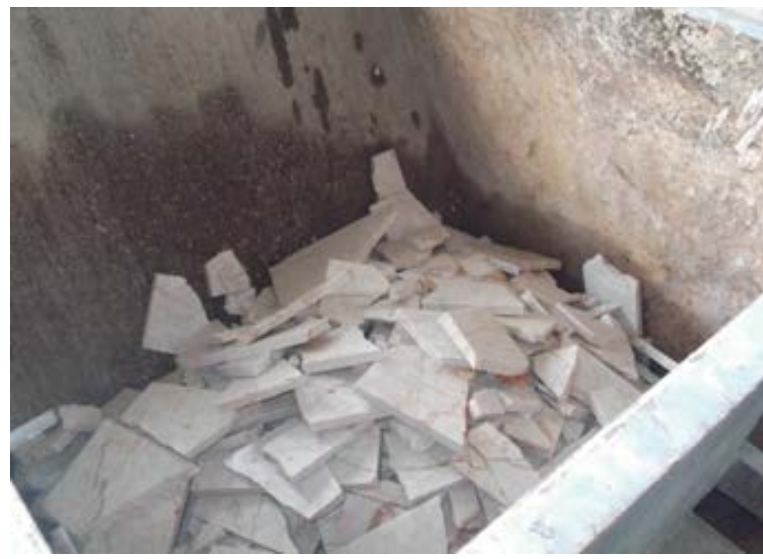

Figure 1: (b) Waste in marble company, Bilecik, Turkey.

plasticity and strength properties of red tropical soils were improved significantly with marble dust usage. Mishra et al. [14] indicated that marble waste might be mixed with soil used for road infrastructure and filling material. Zorluer and Usta [15] examined whether marble dust might be used for improving clay in swelling tests. They said that waste marble dust might be used for improving the soil. Sabat et al. [16] added varying degrees of fly ash and marble dust to a swelling soil. They determined that geotechnical properties of soils were improved significantly by increased amounts of fly ash-marble dust usage. Taspolat et al. [17] investigated the effects of marble dust used for layers of waste storage on freezing and thawing properties. They indicated that adding $10 \%$ and $15 \%$ marble dust to impermeable clay layers increased the soil strength against environmental conditions. Ural et al. [18] studied utilization of the waste marble in soil improvement of clayey soils and as a fine aggregate in concrete production. Physical, mechanical and physico chemical characteristics were determined on clayey soils with marble dust additive. The test results showed that some improvement occurred in behavior of clay soil. Also, the cutting waste of marble sludge will use as a filler material instead of fine aggregate in concrete production. Yildiz [19] evaluated marble dust and waste parts the availability of road-building. They said that in road construction, the use of marble dust and tracks may be appropriate and, in soil stabilization, with the use of dust waste, increased efficiency of at least 10 times. Gürer [20] and Lima [21] said that waste marble pieces can be evaluated as road base and sub-base material. Excess of that required in the construction industry raw materials is needed the use of raw materials and energy consumption by minimizing. Therefore, the use of recycled material in the road sub-aggregate material or as an additive material in clayey soils has contributed to the significant amount of the national economy. This contribution emerges in material transport (shipping) or laying out as the work machine rental, fuel costs, labor costs, transportation costs, as the reduction of discharge-storage costs.

\section{Formation of Marble Waste}

Marble wastes are generated as a waste during the process of cutting and polishing. To come to the desired properly marble blocks, marble is cut into smaller blocks. Relatively large quantities of marble waste are becoming fragmented during this cutting (Figure 2A and 2B). Marble and another stone industry produces large amounts of waste which causes environmental problems. Marble waste from the processing plant as part size can be as two different products. The first product is large-sized pieces of marble waste, the second product is dust waste maximum part size up to $2 \mathrm{~mm}$ reach. Large-sized piece of marble wastes are disposed randomly nature show that the waste area or local government and very bad pollution demonstrate the image. Marble dust is settled by sedimentation and than, the marble dust is slurry obtained first and is left wet state at nature. In addition to forming dust in summer and threatening both agriculture and public health. Large size piece of waste that can be used as structural elements in the construction industry, the waste dust can be used directly in different industries. Part of waste concrete aggregate used as filling material, compacted road surface marble dust can be used in cement production, glass production, the film material in concrete and, as an additive material in soil improvement.

\section{Evaluation of Energy savings usıng Waste of Marble}

With population growth, is rapidly exhausted energy reserves of fossil fuels to meet a significant portion of its needs. The use of energy resources in an efficient manner is of great importance, due every day fossil fuels (coal, oil and natural gas) the reduction in the reserve. A significant amount of energy used recoverable, with energy-saving measures to do. Energy savings can be achieved in such as industry, buildings and transport sector to be taken measures. Energy savings are realized, more wise use of energy resources and to allow reduction of energy costs by making studies. In addition, it is of utmost importance, in terms of the reduction of environmental problems. Overall we can say the main energy saving methods in industry; improvement of combustion efficiency, waste water heat recovery, waste heat recovery from the flue gas, air to air heat recovery, compressor capacity control, limestone inhibitors and fleet of fuel-saving [22,23]. Hanieh et al. [24]

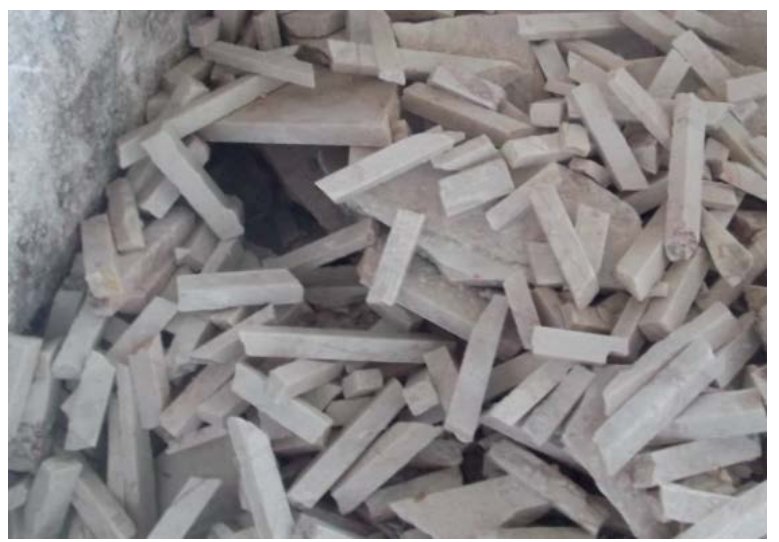

Figure 2: After the cutting of marble plates, marble waste. (a) Marble pieces 


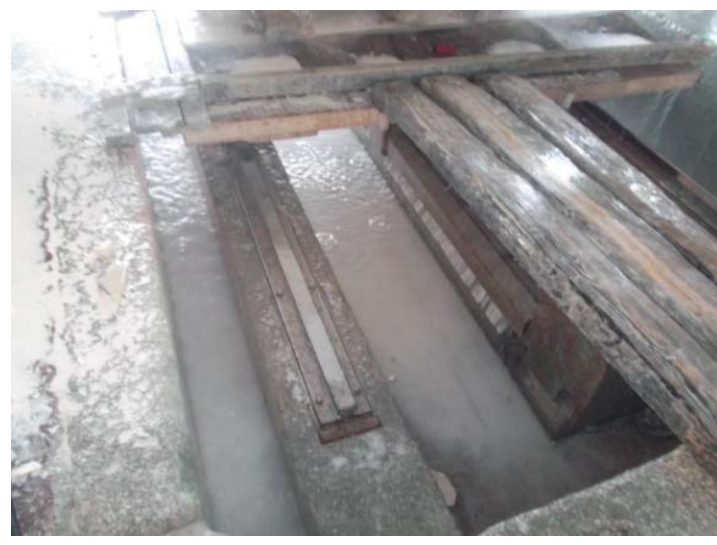

(b) Marble dust

are given a flowchart for complete life cycle of the Stones. Lifecyle flowchart shows that tarting from the extraction process of the stones from rocks to using shaped stones in the building and possibility of recycling stones after buildings.

Energy saving to be obtained as aggregate of marble pieces and the marble dust by used as additives is obtained with the disappearance of the cost of extracted the rubble from the quarry using explosives, of preparation compressor or hands extract out of the quarry, of the installation of the wheel loader, of breaking with the crusher-sieved the classification, of overloading the transport vehicle and of the transportation to the construction site. Also transportation to the same equation will be used in natural and waste materials are the most important factor in moving away. Ylldız [19] said that for piece of marble waste for road construction in the area of $68.21 \mathrm{~km}$ away, even if a quarry next to the construction site, the same cost gives with the use of natural materials to $68.21 \mathrm{~km}$ from the use of waste brought to the piece of marble. Briefly, the marble using waste materials as aggregates or additives savings the energy used by the machinery and equipment used in quarries. Thus, the evaluation of the marble waste from industrial waste become the economy is contributing by providing both a reduction the environmental pollution and energy saving. Because a large number of factories in Bilecik City, Turkey; as example it can be give this city. Marble pieces was seen to be proper materials as sub-base/ base materials according to Republic of Turkey Highways Technical Specification criteria. Consequently, it was made cost analysis and it was seen to suitable to be used the marble waste in order to reduce transport costs in the evaluation of the road construction in the region.

\section{Conclusions}

Natural stone such as marble cutting business by producing and processing enterprises are used natural resources as production inputs. But natural resources, can not be put in place again when consumed. Accordingly, these businesses should use resources efficiently and making production environment are also protected. As for environmental protection made of environmentally friendly production, minimization of harmful waste and recycling should be provided. The purpose of all these studies, To reduce the negative effects of the surrounding reducing waste levels,to reduce the quest for new sources of raw materials and provide energy savings.

In particular, a large amount of raw materials required by road, rail and environmental pollutants in the construction of structures such as airport has industrial solid waste countries' potential to contribute to energy saving after making the necessary experiments using. The energy in a country's economic and social development in terms of direct influence, for use in any area of the material to be recycled it is also important in raising the living standards of humanity. In addition, the use of waste materials in construction industry will help to decrease environmental pollution and economic costs. Thus, utilization of marble waste different industries has a beneficial potential for sustainable construction technologies. The use of the replacement materials offer cost reduction, energy savings, arguably superior products, and fewer hazards in the environment.

\section{References}

1. Rassin AG (2011) A comprehensive study of marble industry in Afghanistan Research \& Statistics Department Afghanistan Investment Support Agency.

2. Korai MA, Hussain S, Abro A (2011) A report on marble \& Granite, Trade Development Authority of Pakistan.

3. Öztürk M (2009) Environmental Pollution Resulting from Marble Cutting. Grand National Assembly of Turkey Environment Commission, Ankara, Turkey (in Turkish)

4. Akyarlı A, Kavak A, Atay S, Alkaya S (2009) Stabilization of Clayey Soil with Lime. TSE- Standard Economic and Technical Journal 48:108-112 (in Turkish)

5. Uğurlu A (1996) Effect of the use of Mineral Filler on the Properties of Concrete. 1. National Crushed Stone Symposium 303-323 (in Turkish).

6. Ünal O, Kibici A (2001) A Research Lsing Waste-Marble Dust in the Concrete Production. Turkey III Marble Symposium, Afyon Turkey 317-325 (in Turkish).

7. Agrawal V, Gupta M (2011). Expansive Soil Stabilization Using Marble Dust, International Journal of Earth Sciences and Engineering 4: 59-62.

8. Topçu IB, Bilir T, Uygunoğlu T (2009) Effect of waste marble dust content as filler on properties of self-compacting concrete. Construction and Building Materials 23: 1947-1953.

9. Corinaldesi V, Moriconi G, Naik TR (2010) Characterization of marble powde for its use in mortar and concrete. Construction and Building Materials 24: 113117

10. Tassdemir C, Atahan HN (1996) Effect of Microfiller Materials on the Mechanical Properties and Durability of Concrete. National Crushed Stone Symposium 251-265 (in Turkish)

11. Karaşahin M, Terzi S (2007) Evaluation of Marble Waste Dust in the Mixture of Asphaltic Concrete. Construction and Building Materials 21: 616-620.

12. Seung WL, Fishman KL (1993) Waste products as highway materials in flexible pavement system. Journal of Transportation Engineering 119: 433-449.

13. Okagbue CO, Onyeobi TUS (1999) Potential of marble dust to stabilise red tropical soils for road construction, Engineering Geology. Elsevier Science 53: 3 71-380.

14. Mishra AK, Mathur R, Goel $P$ (2011) Marble slurry dust in roads- an apt solution for industrial waste. Jl. Of Highway Research Bulletin 65: 83-91.

15. Zorluer I, Usta M (2003) Stabilization of Soils By Waste Marble Dust, IV Marble ermer Symposium (Mersem '2003) Proceedings Book, Turkey, 305-311 (in Turkish).

16. Sabat AK, Behera SN, Dash SK (2005) Effect of Flyash- Marble Powder on the Engineering Properties of an Expansive Soil. Indian Geotechnical Conference 269-272.

17. Taşpolat LT, Zorluer I, Koyuncu H (2006) Effect of Freeze - Thaw Marble Waste Powder on impermeable clay layers. Electronic Journal of ConstructionTechnologies 2: 1-16.

18. Ural N, Karakurt C, Cömert AT (2014) Influence of marble wastes on soil improvement and concrete production. Journal of Material Cycles and Waste Management 16: 500-508.

19. Yıldız AH (2008) Evaluation of Road Construction Waste Marble Powder. PhD Thesis, Süleyman Demirel University, Turkey (in Turkish)

20. Gürer C (2005) Using Waste Marbles Within the Asphalt Pavements, Master Thesis, Afyon Kocatepe Üniversitesi. 
Citation: Ural N (2015) Evaluation of Energy Conservation with Utilization of Marble Waste in Geotechnical Engineering. Int J Waste Resour 5: 189. doi: 10.4172/22525211.1000189

Page 4 of 4

21. Lima $H$ (2002) Applicability of marble quarry waste in pavement layers, Proceedings of the Seminar, Appropriate use of natural materials in road, Ulann Baator (Mongolia).

22. Filik BÜ, Kurban M (2007) Effect of Boiler Efficiency in Industry and Energy Saving Analysis, EVK'2007 2. Energy Efficiency and Quality Symposium, Kocaeli, Turkey (in Turkish)
23. Kavak K (2005) Energy Efficiency in the world and Turkey and, Evaluation of Energy Efficiency in Turkish Industry, General Directorate of Economic Sectors and Coordination, Turkey, publication no: DPT: 2689(in Turkish).

24. Hanieh AA, AbdElall S, Hasan A (2013) Sustainable development of stone and marble sector in Palestine. Journal of Cleaner Production 84: 581-588. 